\title{
FLOOD AND LANDSLIDE EVENTS, PEYTO GLACIER TERMINUS, ALBERTA, CANADA, 11 - 14 JULY 1983
}

\author{
By P. G. JOHNSON \\ (Department of Geography, University of Ottawa, Ottawa, Ontario K1N 6N5, Canada) \\ and J. M. POWER \\ (National Hydrology Research Institute, Environment Canada, Ottawa, Ontario K1A 0E7, Canada)
}

\begin{abstract}
Two flood waves from the terminus of Peyto Glacier occurred as a result of very high precipitation in early July 1983 and a landslide which exposed a large section of ice-cored moraine. The flood waves induced erosion, and subsequent melt, of the moraine and deposited an estimated $6000 \mathrm{~m}^{3}$ of gravel in the valley. The majority of the deposition occurred in an area approximately $200 \mathrm{~m} \times 20 \mathrm{~m}$ to depths of $3 \mathrm{~m}$ at the site of the National Hydrology Research Institute gauging station $1 \mathrm{~km}$ from the glacier terminus. The initial flood washed away most of the equipment from the site and the gravel deposition totally destroyed the rest of the installation. These events appear to be unique in the period that hydrological records have been maintained for Peyto Creek.
\end{abstract}

RÉsumÉ. Crues, glissement de terrain et lave torrentielle au front du glacier Peyto, Alberta, Canada, 11-14 juillet 1983. Les très fortes précipitations des premiers jours de juillet 1983 ainsi qu'un glissement de terrain qui a mis à nu le noyau de glace d'une moraine ont provoqué deux crues de i'émissaire du glacier Peyto. Les crues érodant la moraine et entrainant ia fusion du noyau de glace ont déposé quelque $6000 \mathrm{~m}^{3}$ de graviers dans la vallée. L'essentiel des dépôts couvre ure surface de $200 \mathrm{~m}$ x $20 \mathrm{~m}$ sur $3 \mathrm{~m}$ d'épaisseur à l'emplacement

\section{INTRODUCTION}

A series of catastrophic hydrological and geomorphological events occurred at the terminus of Peyto Glacier, Alberta, between 11 and 14 July 1983. These events produced rapid erosion of the massive ice-cored moraine below the present glacier te:minus and deposited approximately $6000 \mathrm{~m}^{3}$ of gravel in the braided stream bed $1 \mathrm{~km}$ below the present terminus. Peyto Glacier is a small outlet glacier situated on the east side of the Wapta Icefield in the Waputik Range of the Canadian Rocky Mountains (Fig. 1). The glacier is fed from a number of smail basins below Mountains Thompson, Rhonda, and Baker, and Trapper Peak and at altitudes up to $3172 \mathrm{~m}$ a.s.l. It covers an area of 13.4 $\mathrm{km}^{2}$ and terminates at approximately $2090 \mathrm{~m}$ a.s.1. The basin area is approximately $23.0 \mathrm{~km}^{2}$ and the glacierized component of the basin is therefore $58.3 \%$. Since 1965 the glacier has been studied extensively as an International Hydrological Decade site and subsequently as a continuing programme of Environment Canada. Peyto Glacier has one of the best glaciological, hydrological, and climatological records of any basin in Canada, which indicates that the glacier has been retreating since the first photographic record in 1896 . The terminus lobe is now thin and slow-moving with only $15 \%$ of the original glacier area and probably considerably less of the total ice volume. de la station de jaugeage de l'Institut National de Recherche Hydrologique situé à $1 \mathrm{~km}$ du front du glacier. La plupart des équipements de la station ont été entrainés au début de la crue et le reste entièrement détruit par le dépôt de sédiments. Aucun évènement de cette ampleur ne s'était produit depuis le débur des observations sur le Peyto Creek.

Zusammenfassung. Flutwellen und Muren an der Zunge des Peyto Glacier, Alberta, Kanada, 11-14 Juli 1983. Zwie Flutwellen aus der Zunge des Peyto Glacier, verursacht durch sehr hohe Niederschlăge zu Anfang Juli 1983 und eine Lawine legten einen grossen Teil der mit einem Eiskern erfüllten Morăne frei. Die Flutwellen führten zur Erosion und anschliesssenden Abschmelzung der Morăne und lagerten schătzungsweise $6000 \mathrm{~m}^{3}$ Schotter in das Tal ab. Die stärkste Ablagerung trat in einem Bereich von etwa $200 \mathrm{~m} \mathrm{x} 20 \mathrm{~m}$ bis zu $3 \mathrm{~m}$ Mächtigkeit an der Pegelstation des National Hydrology Research Instituts $1 \mathrm{~km}$ unterhalb der Gletscherzunge ein. Die anfängliche Flutwelle schwemmte den Grossteil der Stationseinrichtung weg; die Schuttablagerung zerstörte den Rest der Installationen total. Diese Ereignisse erscheinen einzigartig seit der Zeit, da hydrologische Aufzeichnungen für den Peyto Creek geführt werden.

\section{GEOMORPHOLOGY}

The geomorphology of the basin is dominated by Neoglacial and Recent moraines perched on the rock face along the east side of the valley and as a sharp ridge down the west side between Caldron Creek and Peyto Creek. These moraines descend a large rock step into the braided outwash section of the valley floor and terminate before a moraine constriction of the valley at the apex of the Peyto Lake delta. Parts of these moraines are still ice-cored.

The discharge stream of the glacier is deeply incised into bedrock and is covered in places by a massive section of debris-covered stagnant glacier ice. Melt-out of the ice-cored moraine has been slow and has in particular been retarded by the thick till cover over most of the ice. Ice has normally only been exposed at the inflow and the outflow of the drainage tunnel.

\section{WEATHER CONDITIONS}

The climatic pattern of the basin is typical of high mountain areas in that it is highly variable through the season and between seasons. The conditions at Peyto Glacier are controlled by the tracks of depressions from the Pacific Ocean or the Arctic Frcnt and on the 

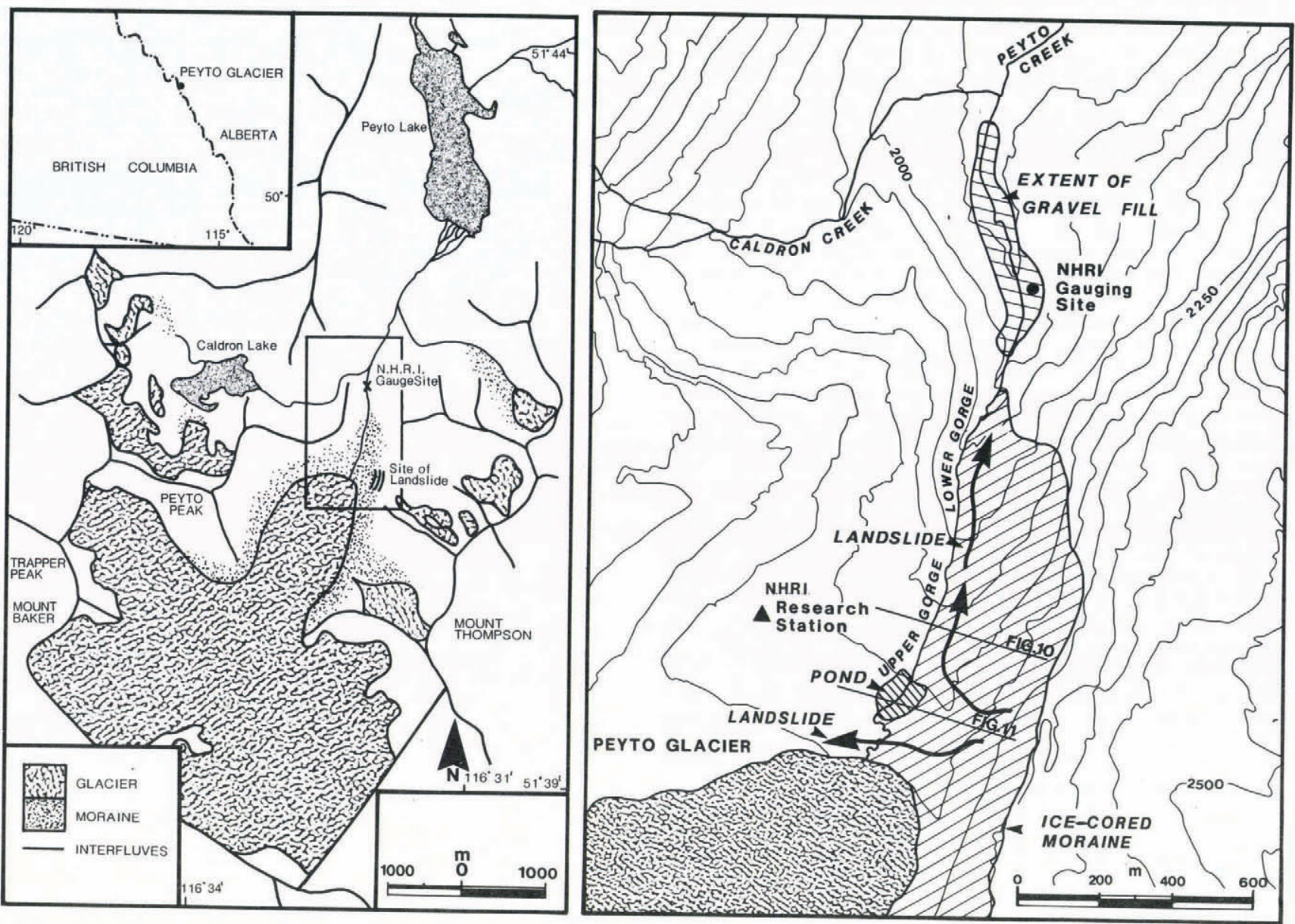

Fig. 1. Location map of Peyto Glacier and the sites of the stream gauge, the landslide, and features referred to in text.

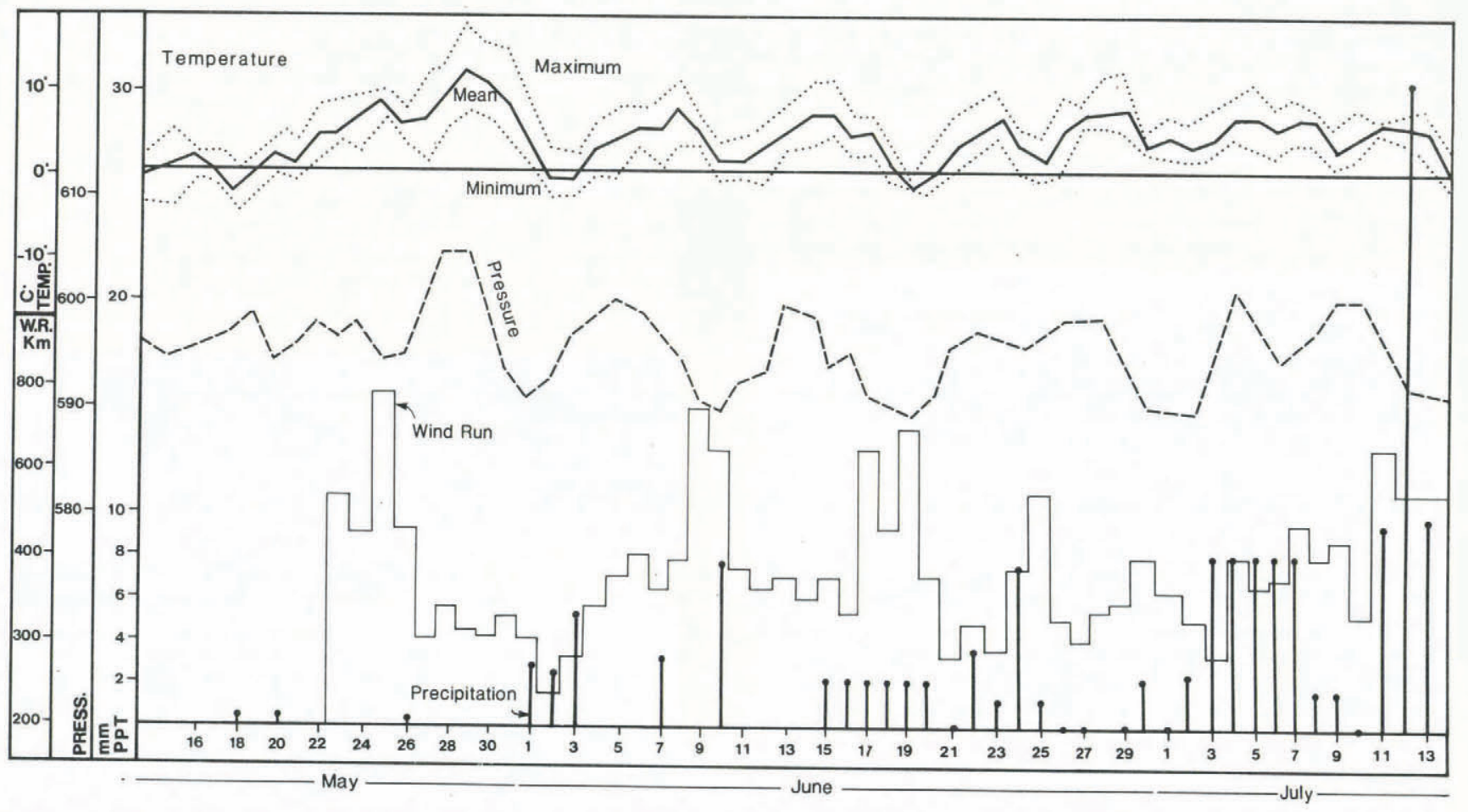

Fig. 2. Summary of the climatic conditions of summer 1983 leading up to the floods and landslide of 11-14 July. 
strength of the pressure systems in the continental interior. There has been extensive research on aspects of the climatology of the basin (Goodison [1971], 1972; Munro, unpublished; Munro and Young, 1980) and on glacier mass balance and the prediction of run-off from the basin (Derikx, 1973; Power and Young, [1979]; Gottlieb, 1980; Young, 1981).

During the 1983 season records were maintained at the glacier berween 14 May and 13 September. From 19 May to 30 June the climatic conditions reflected the typical patterns which occur in the high basins of the Rocky Mountains. A series of low-pressure systems crossed the area with associated temperature and precipitation fluctuations (Fig. 2). The only climatic variation of note was the prolonged influence of up-valley winds in early June associated with the rapid drop in pressure between 29 May and 1 June. Total precipitation during the early season can be classed as normal with maxima of $7.6 \mathrm{~mm}$ on 10 June and 24 June but with no extreme events. Commencing 2 July there were two weeks of unusual weather conditions which culminated in the events of 11 to 14 July. On 2 July pressure started to rise and stayed relatively high without any rapid changes. Temperature in this period was unusually constant with mean daily values between $6^{\circ} \mathrm{C}$ and $3{ }^{\circ} \mathrm{C}$. Average humidity was about $60 \%$ through the period. The precipitations pattern, however, was exceptional. Steady precipitation between 2 and 8 July resulted in a total of $44 \mathrm{~mm}$. During 11 and 12 July the area was on the edge of a major storm to the west which contributed $30 \mathrm{~mm}$ (measured) with wind speeds between $30 \mathrm{~km} \mathrm{~h}^{-1}$ and $40 \mathrm{~km} \mathrm{~h}^{-1}$. This precipitation caused rapid run-off from the glacier surface and from the adjoining basin already saturated from the 2 to 8 July rainfall. During 12 and 13 July the rainfall abated slightly but the area still received a further $9.7 \mathrm{~mm}$. During the night of 13 to 14 July an intense thunderstorm contributed an additional $15.5 \mathrm{~mm}$ of rain concentrated into a $2 \mathrm{~h}$ period. The total precipitation for the first two weeks of July was in excess of 100 mm.

\section{EVENTS AT PEYTO GLACIER TERMINUS, 11-12} JULY

During sediment sampling at the glacier terminus on the morning of 11 July, before the first intense storm, discharge was visibly rising and a powerful hydrostatic resurgence at the terminus was forcing large blocks of glacier ice (up to $1 \mathrm{~m} \times 0.5 \mathrm{~m} \times 1 \mathrm{~m}$ ) into the river course. The intense rainfall of the night of 11 to 12 July produced an immediate rapid run-off from the basin which augmented the already high discharge from the glacier. The high discharge and the ice blocks were directed through the ice-cored moraine tunnel across the rock step below the terminus. During the night the

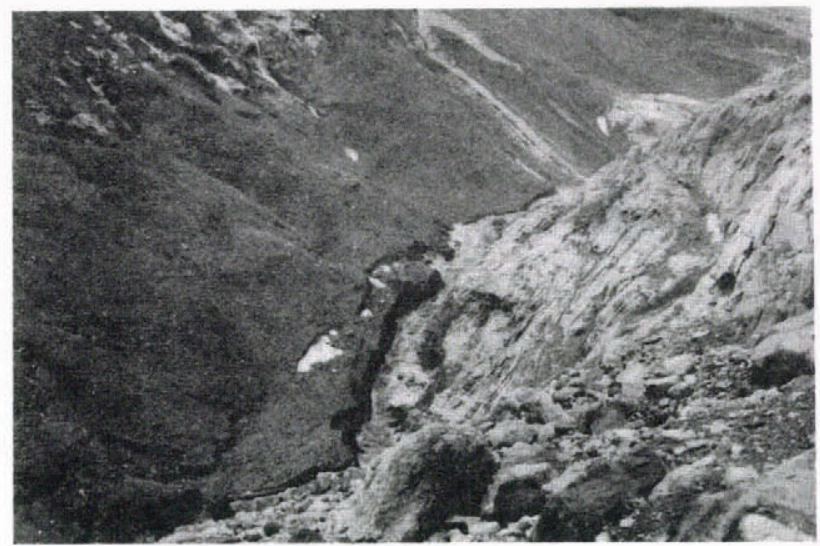

Fig. 3. The ice-cored moraine after the flood of 11-12 July. Note the flood plain surface in the lower left quadrant, the incision of the stream into the ice core, and the mud-flow activity on the moraine in the upper right quadrant.

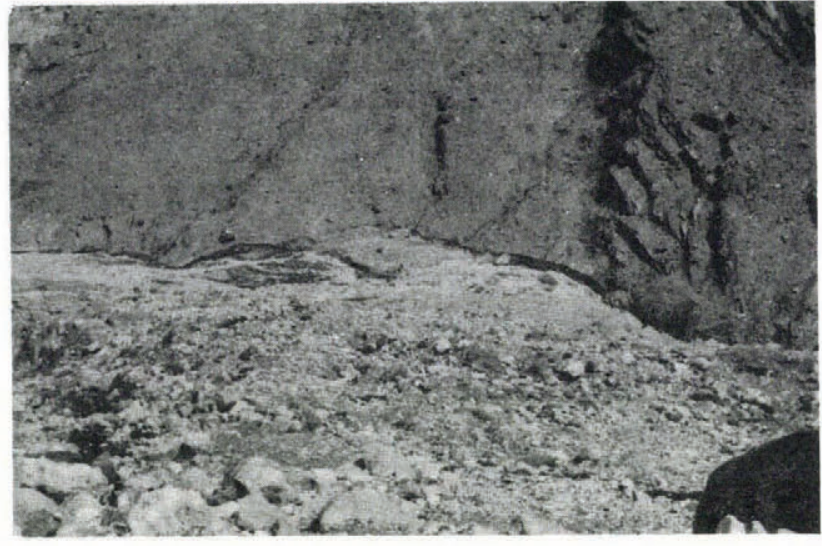

Fig. 4. The gauging site after the initial flood event. Note the position of the white-painted survey boulder. (Two figures on the point of the gravel bar in the centre of the photograph provide scale).

tunnel was unable to accomodate the increasing discharge and the water backed up above the entrance. The resultant pond in the gorge attained a depth of about $30 \mathrm{~m}$ before overflowing across the ice-cored moraine surface. The overflow rapidly developed into a flood wave removing the till cover of the moraine and initiating erosion of its ice core (Fig. 3). The flood wave cascaded over the end of the ice-cored moraine through the gorge waterfall sections of the channel and across the National Hydrology Research Institute (N.H.R.I) stream-gauging site. The flood wave destroyed most of the gauge site, removing all instrumentation and leaving standing only the stilling well. The stream course also changed, migrating towards the east side of the valley. Figure 4 shows the gauging site at midday on 12 July. The large, white-painted, survey boulder in the left-centre of the photograph was sited $30 \mathrm{~m}$ away from the preflood stream course. The pond in the upper gorge remained full and discharged over the moraine throughout the 12 and 13 July. Run-off from the east side of the valley started the degradation of the ice-cored moraine at the higher moraine trim-line. Debris from collapse of this moraine and from small mudflows initiated across the ice core were gradually infilling the pond (Fig. 5). During 12 July this infilling totally sealed of $f$ the old entrance to the stream tunnel channel. The new surface stream was rapidly incising into the ice core and inducing slumping of till of the rest of the moraine.

Judging from the changes in the stream course at the gauging site, the flood wave transported a large volume of debris, but estimates of volume transported were precluded by subsequent events. The water height can be inferred from the fact that the instrumentation was swept off the top of the stilling well. This was probably $3 \mathrm{~m}$ above normal water-levels in the channel.

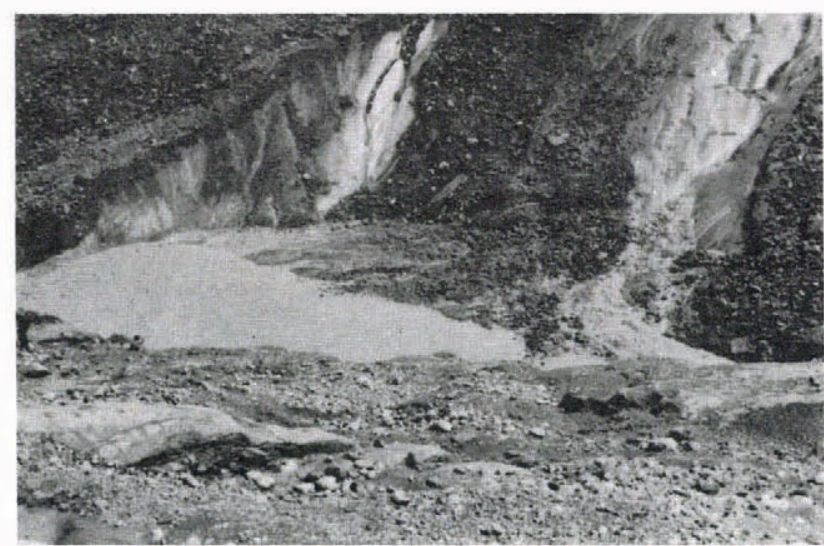

Fig. 5. The pond in the gorge above the ice tunnel infilling with mudflow debris on 12 July. 
A very rough projection of this water-level across the valley gives a cross-section of $80-100 \mathrm{~m}^{2}$ and suggests that the instantaneous discharge may have been at least in the $200-300 \mathrm{~m}^{3} \mathrm{~s}^{-1}$ range.

The hydrological records from the gauging station indicate very variable daily discharges with peak daily flows up to $1500 \times 10^{3} \mathrm{~m}^{3} \mathrm{~d}^{-1}\left(17.3 \mathrm{~m}^{3} \mathrm{~s}^{-1}\right)$ and maximum measured flows up to $26 \mathrm{~m}^{3} \mathrm{~s}^{-1}$. The seasonal regime is extremely uneven with peak discharge occurring between early July to mid August or with a number of peaks of equivalent magnitude spread between late June and early September depending on the seasonal weather conditions. Small flood events have occurred but there are no data on discharge and severe damage to installation has not previously been reported. The range of daily discharges in June and July has been between $100 \times 10^{3} \mathrm{~m}^{3} \mathrm{~d}^{-1}$ and $1500 \times 10^{3} \mathrm{~m}^{3} \mathrm{~d}^{-1}$ (1.2 $\mathrm{m}^{3} \mathrm{~s}^{-1}$ and $17.3 \mathrm{~m}^{3} \mathrm{~s}^{-1}$ ). (With a mean annual discharge of $45 \times 10^{6} \mathrm{~m}^{3}$ the flow is distributed throughout the season: Jan. $0.4 \%$, Feb. $0.4 \%$, Mar. $0.4 \%$, Apr. $0.4 \%$, May $0.7 \%$, June $16.4 \%$, July $30.0 \%$, Aug. $35.6 \%$, Sept. $12.3 \%$, Oct $2.0 \%$, Nov. $1.0 \%$, Dec. $0.4 \%$.)

\section{EVENTS AT PEYTO GLACIER TERMINUS, 13-14} JULY

Precipitation abated slightly through to the evening of 13 July but the intense thunderstorm of the evening of 13 July added $15.5 \mathrm{~mm}$ of rain to a saturated basin and a glacier hydrological system which was already at capacity. The immediate result of the thunderstorm was the collapse of the perched lateral moraine of $f$ the east side of the valley. This collapse stripped the till cover of $f$ the ice-cored moraine on the east side as the slide

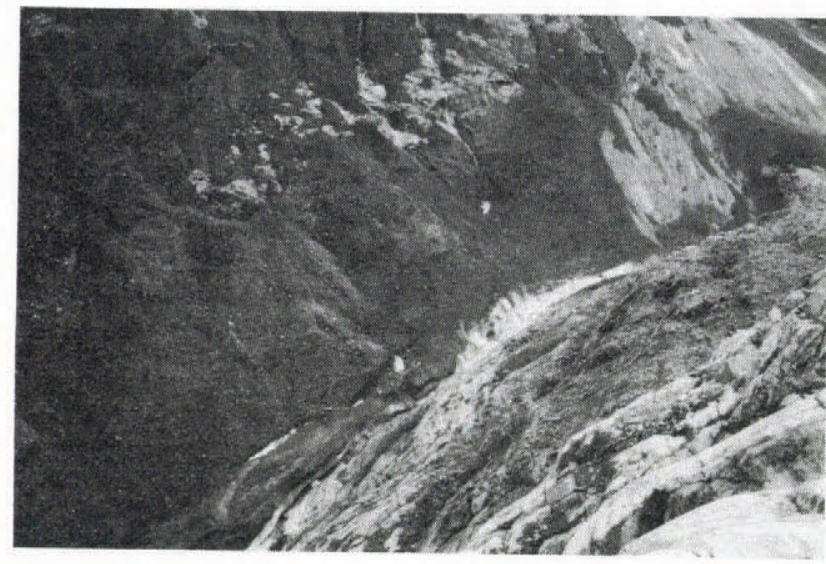

Fig. 6. The ice-cored moraine after the landslide and the flood. Note the meandering track of the landslide across the moraine, re-incision of the stream into the ice core, and the total exposure of the ice in the upper right quadrant of the photograph. Comparison with Figure 3 demonstrates the magnitude of the ice exposure.

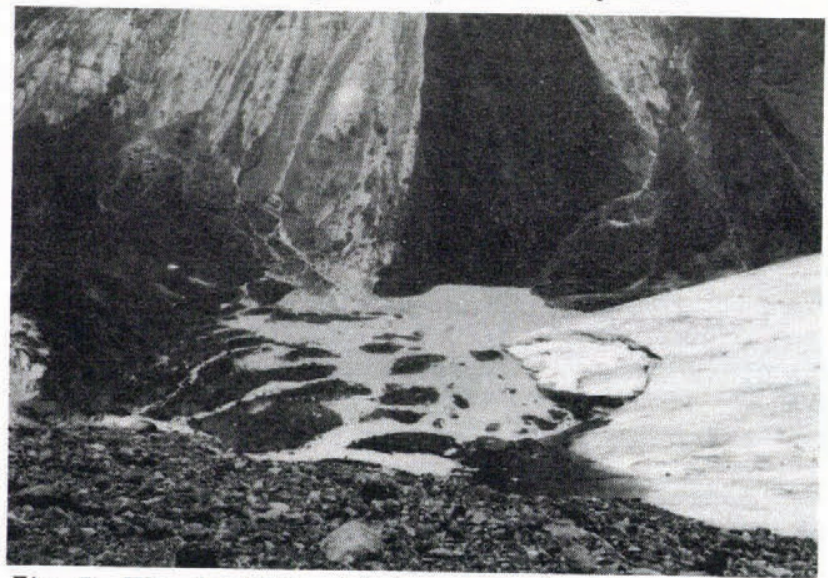

Fig. 7. The landslide debris across the terminus of the glacier.

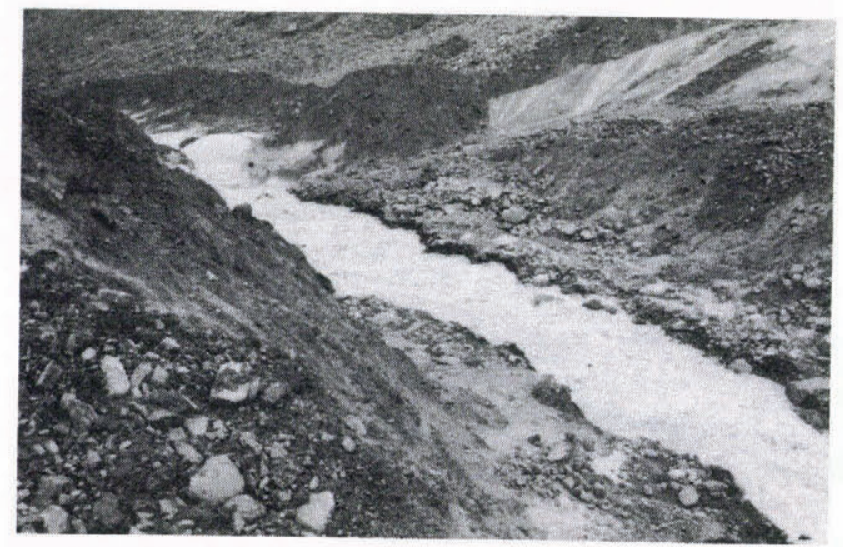

Fig. 8. The pond site in the gorge infilled by landslide material on 14 July. The stream has established a course across the landslide debris.

moved down-slope (upper right Fig. 6). At the base of the slope the slide divided about a rock bar into two sections, one moving across the outwash at the glacier terminus and partially up on to the terminus (Fig. 7). The second diverted down-valley (Fig. 6) filling the pond site (Fig. 8) and flowing across the ice-cored moraine as far as its terminus (Fig. 6). The result was the damming of the discharge at the glacier terminus and above the ice-cored moraine. The release of these dams, occurring during the night but inferred to be a release at the glacier followed rapidly by a release down-valley, produced a flood wave of rock and mud down the valley and across the old gauging site, totally obliterating the remaining equipment. Material was initially deposited up to $5 \mathrm{~m}$ deep in the gorge above the gauge but this was subsequently swept away. Roughly $2-3 \mathrm{~m}$ of rock were deposited over the gauging site for a distance of $100 \mathrm{~m}$ and thinning down-valley for a further $300 \mathrm{~m}$. The total estimated deposit was $6000 \mathrm{~m}^{3}$ of gravel. The configuration of the gauging site on the morning of 14 July is illustrated by Figure 9 with the bulk of the gravel in the lower centre of the photograph. For comparison with Figure 4 the position of the survey boulder should be noted. In Figure 9 the boulder has been displaced $2 \mathrm{~m}$ down-slope.

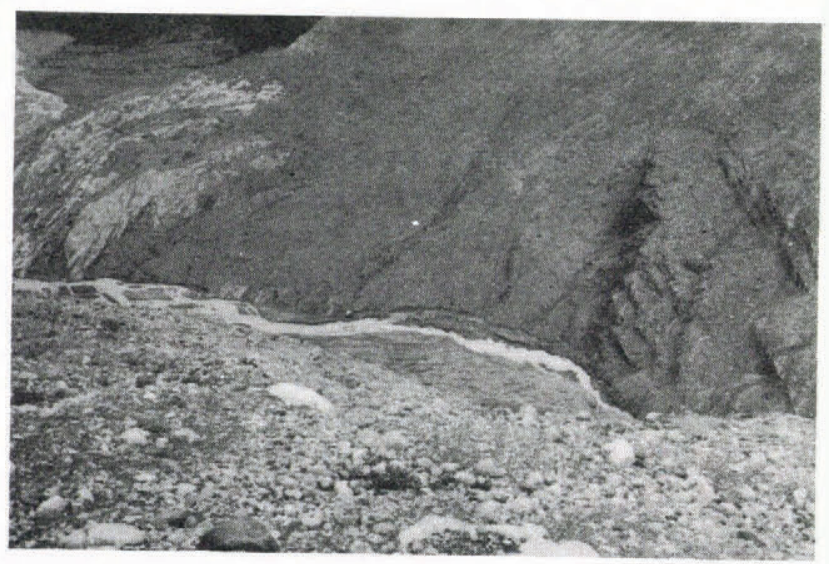

Fig. 9. The gauging site after the landslide and flood event Note the change in position of the survey boulder and the changes in the stream channel.

\section{CHANGES AT THE ICE-CORED MORAINE (Fig. 10)}

The overflow of the moraine by the first flood, which incised into the ice, was followed by complete blockage of the channel by the landslide moving down-valley. It was finally re-opened as the second flood wave removed the landslide debris and recommenced incision into the ice core. This incision 

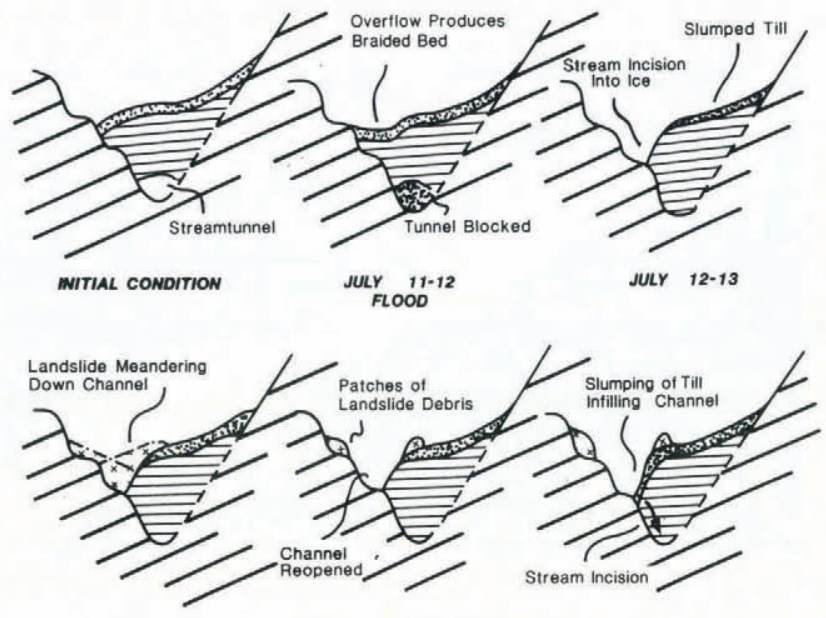

$$
\begin{array}{ll}
\text { JULY } & \mathbf{1 3 - 1 4} \\
\hline \text { Till } & \text { Ice } \\
\hline & \text { Bedrock } \\
\square & \text { Landslide Debris }
\end{array}
$$

JULY 14 JULY 17

Fig. 10. Diagram of the changes at the ice-cored moraine.

had progressed sufficiently by 17 July to allow debris slumping off higher portions of the moraine to partially infill the channel.

\section{CHANGES AT THE GLACIER TERMINUS (Fig. 11)}

The main changes at the glacier terminus were the exposure of the ice core of the deposits on the east side of the valley, initially on a small scale by the mudflows over the ice core but primarily as a result of the massive landslide of 13-14 July. Landslide debris covered the immediate glacier terminus area to depths of $2 \mathrm{~m}$ and this modified the drainage pattern from the glacier. The slide also flowed down-valley and was eventually removed by the flood wave as described above.

\section{CHANGES IN THE FLOOD PLAIN BELOW THE GORGE}

These changes can be illustrated by reference to Figures 4 and 9 and using the white painted survey boulder as the point of reference. Prior to the flood of 11-12 July the boulder was $30 \mathrm{~m}$ from the stream which had a course against the west side of the valley (nearest the camera in the Figures). After the flood the stream course had migrated to the east side of the valley, some deposition had occurred at the site but the stilling well was in place. The flood wave had eroded close to the position of the survey boulder. The flood of 13-14 July after the landslide deposited $2-3 \mathrm{~m}$ of gravel and boulders over the whole site ripping apart the stilling well and undermining the surveying rock which subsequently rolled $2 \mathrm{~m}$ down-slope. One section of the stilling well was found $600 \mathrm{~m}$ down-valley. Fresh deposition or reworking of the river gravels occurred for up to $800 \mathrm{~m}$ down-valley and the remains of the equipment from the gauging site were distributed down to the shore of Peyto Lake. Pieces of the steel cable which had been used to anchor the stream gauge had cleanly cut ends and remains of the wire gabions used to protect the stilling well were transported $1 \mathrm{~km}$ from the site.

\section{SUMMARY}

The changes in the morphology of the proglacial area of Peyto Glacier as a result of the events of 11-14 July were dramatic. Although small flood waves and mudflows had been observed by Environment Canada personnel on a number of occasions during the 20 years of research at the site nothing approaching the magnitude of the events described here had been recorded. The evolution of the pro-glacial landscape has been dominated therefore by the very high-magnitude low-frequency sequence of events and this illustrates the importance of the concept of catastrophic process evolution in these areas. The importance of mass wasting processes of low frequency throughout the Rocky Mountains has been proposed by Gardner (unpublished). $\mathrm{He}$ has placed these events in early Holocene and the Neoglacial time but it is apparent that there still exists the potential for these processes to occur. In the light of the observations at Peyto Glacier the concepts of dynamic equilibrium and steady state must be re-evaluated. The observations strengthen one of the authors views (Johnson 1970, 1983, 1984 [a], [b]) that although approaches of, for example, heat flow through till to explain ice-cored moraine degradation are of importance, evolution and formation of landforms in the paraglacial environment must consider the high-magnitude catastrophic event.

\section{ACKNOWLEDGEMENTS}

Dr Johnson wishes to acknowledge the National Hydrology Research Institute, on whose behalf he was at Peyto Glacier, and the students who have been maintaining the research project from May to September each year.

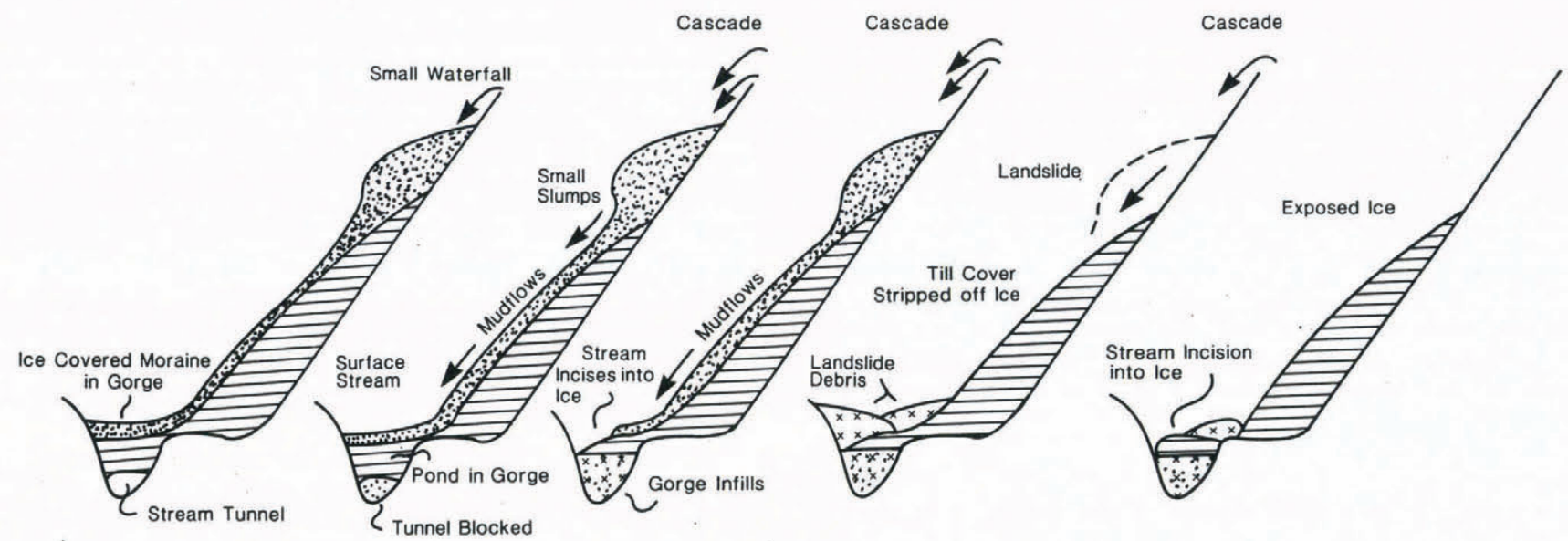

Fig. 11. Diagram of the changes at the glacier terminus. 


\section{REFERENCES}

Derikx, L. 1973. Glacier discharge simulation by ground-water analogue. Union Géodésique et Géophysique Internationale. Association Internationale d'Hydrologie Scientifique. Commission de Neiges et Glaces. Symposium on the Hydrology of Glaciers, Cambridge, 7-13 September 1969, p. 29-40. (Publication No. 95 de l'Association internationale d'Hydrologie Scientif ique.)

Gardner, J. Unpublished. Regional variation of mass wasting processes in the Canadian Rockies. [Paper presented at Canadian Association of Geographers Ontario Division Conference, McMaster University, Hamilton, Ontario, November 1983.]

Goodison, B. [1971]. The relation between ablation and global radiation over Peyto Glacier, Alberta. (In Demers, J., ed. Glaciers. Proceedings of the Workshop Seminar sponsored by Canadian National Committee for the International Hydrological Decade and assisted by University of British Columbia, September 24 and 25 . 1970. Ottawa, Secretariat, Canadian National Committee for the International Hydrological Decade, p. $39-42$.)

Goodison, B. 1972. An analysis of climate and runoff events for Peyto Glacier, Alberta. Ottawa, Environment Canada. Inland Waters Directorate. Water Resources Branch. (Scientific Series, No. 21.)

Gottlieb, L. 1980. Development and applications of a runoff model for snowcovered and glacierized basins. Nordic Hydrology, Vol. 11, No. 5, p. 255-72.
Johnson, P.G. 1971. Ice cored moraine formation and degradation, Donjek Glacier, Yukon Territory, Canada. Geografiska Annaler, Vol. 53A, Nos. 3-4, p. 198-202.

Johnson, P.G. 1983. Rock glaciers, a case for a change in nomenclature. Geografiska Annaler, Vol. 65A, Nos. 1-2, p. 27-34.

Johnson, P.G. 1984 [a]. Paraglacial conditions of instability and mass movement: a discussion. Zeitschrift für Geomorphologie, Bd. 28, Ht. 2, p. 235-50.

Johnson, P.G. 1984[b]. Rock glacier formation by high-magnitude low-frequency slope processes, southwest Yukon Territory. Annals of the Association of American Geographers, Vol. 74, No. 3, p. 408-19.

Munro, D.S. Unpublished. Energy exchange on a melting glacier. [Ph.D. thesis, McMaster University, Hamilton, Ontario, 1975.]

Munro, D.S., and Young, G.J. 1980. A net shortwave radiation model for glacierized basins. Proceedings of the 37th annual Eastern Snow Conference, p. 159-69.

Power, J.M., and Young, G.J. [1979.] Application of the UBC watershed model to Peyto Glacier basin. Canada. National Research Council. Associate Committee on Hydrology. Canadian hydrology symposium: 79. Proceedings. Vancouver, 10-11 May 1979, p. 217-28. (NRCC No. 17834.)

Young, G.J. 1981. The mass balance of Peyto Glacier, Alberta, Canada, 1965 to 1979. Arctic and Alpine Research, Vol. 13, No. 3, p. 307-18. 